Northwestern University School of Law Northwestern University School of Law Scholarly Commons

Faculty Working Papers

2011

\title{
Phony Originalism and the Establishment Clause
}

Andrew M. Koppelman

Northwestern University School of Law, akoppelman@law.northwestern.edu

\section{Repository Citation}

Koppelman, Andrew M., "Phony Originalism and the Establishment Clause" (2011). Faculty Working Papers. Paper 3.

http://scholarlycommons.law.northwestern.edu/facultyworkingpapers/3 


\title{
PHONY ORIGINALISM AND THE ESTABLISHMENT CLAUSE
}

\author{
Andrew Koppelman ${ }^{*}$
}

\begin{abstract}
[N] a amount of repetition of historical errors in judicial opinions can make the errors true.
\end{abstract}

The question this Symposium addresses-"originalism, for or against?"- is an odd one. In some sense, all constitutional interpreters are originalists. We are all offering interpretations of the language of a text, making claims about what the text means. When we offer interpretations, we are claiming that our interpretation is in some way consistent with what the authors of the text originally wrote. There is obviously room for disagreement, particularly when the text uses large, vague concepts like "equal protection" and "establishment of religion." Even the most expansive interpretation of those phrases, however, claims to rely on the same general concepts that were laid down by the Framers, who knew what they were doing when they chose to use very abstract language. ${ }^{1}$ Moreover, as Thomas Colby and Peter Smith have shown, originalism now means so many different things to so many different writers that it is not a single theory that one could be for or against. ${ }^{2}$ The better question would be "originalism, which?"

\footnotetext{
* John Paul Stevens Professor of Law and Professor of Political Science, Northwestern University. Thanks to Marcia Lehr for research assistance, and to Jack Balkin, Steve Calabresi, Thomas Colby, Kurt Lash, Douglas Laycock, Michael Rappaport, and Steven D. Smith for comments on earlier drafts. This Article's unpleasant strategy, of pretending that "originalist" judges are sincerely trying to discern the original meaning and then seeing how well they have succeeded, is inspired by Bruce Ackerman, Robert Bork's Grand Inquisition, 99 YALE L.J. 1419 (1990) (book review). For that and much else, this Article is dedicated to him.

$\dagger$ Wallace v. Jaffree, 472 U.S. 38, 107 (1985) (Rehnquist, J., dissenting).

1 Thus, for example, Ronald Dworkin, the bête noire of originalists, thinks that the abstract clauses of the Constitution were intended to make interpreters focus on abstract moral concepts. "The clauses are vague only if we take them to be botched or incomplete or schematic attempts to lay down particular conceptions. If we take them as appeals to moral concepts they could not be made more precise by being more detailed.” RONALD DWORKIN, TAKING RIGHTS SERIOUSLY 136 (rev. ed. 1978).

2 Thomas B. Colby \& Peter J. Smith, Living Originalism 1-3 (GWU Legal Studies Research Paper No. 393, 2008), available at http://papers.ssrn.com/sol3/papers.cfm?abstract_id=1090282. The same point has been made about the specifics of "originalist" interpretations of the Establishment Clause: different scholars, looking at the same evidence, have reached widely varying conclusions. See Frank Guliuzza III, The Practical Perils of an Original Intent-Based Judicial Philosophy: Originalism and the
} 
This Article does not attempt to evaluate originalism as such. Instead, it scrutinizes originalism's specific practice in one doctrinal area, by three practitioners who matter: Chief Justice William Rehnquist and Justices Antonin Scalia, and Clarence Thomas. This Article shows that their specific "originalist" interpretations of the Establishment Clause are remarkably indifferent to the original purposes of that clause. This is not necessarily a criticism of originalism per se. However, the abuse of originalist scholarship that these judges have practiced raises questions about what originalist scholars are actually accomplishing.

Begin with some familiar puzzles of Establishment Clause interpretation. What does the clause have to say about Ten Commandments displays in schools or courthouses? About curricula that include "creation science"? About school prayer?

The proper originalist way to undertake these inquiries would be to look at the ideas of the Framers and ratifiers of the Constitution to discern why establishment of religion was regarded as a bad thing and what principle condemned it. The interpreter would then try to figure out how that principle applied to the case being decided.

I would have thought that the preceding paragraph was uncontroversial. $^{3}$ Remarkably, however, there has been an effort to expel such principled considerations from the interpretation of the clause. It has been conducted by the self-styled "originalists" on the Supreme Court-Justices Scalia and Thomas-and, before them, the late Chief Justice Rehnquist. Their arguments are a remarkable congeries of historical error and outright misrepresentation. There is a serious originalist inquiry to be done into the meaning of the Establishment Clause, but none of the "originalist" judges on the Court appear to have the slightest interest in undertaking that inquiry.

Chief Justice Rehnquist and Justices Scalia and Thomas have each followed very different strategies in their efforts to unmoor the clause from its original purposes. Their efforts have, however, had two characteristics in common: they rest on dreadful historical scholarship, and they conveniently coincide with the agenda of the Republican party.

\section{THE VARIETIES OF PHONY ORIGINALISM}

The most remarkable thing about the "originalist" interpretation of the Establishment Clause is the consistency of its conclusions. The historical evidence that purports to be the basis for the interpretation is mercurial; it changes from one Justice to the next while the bottom line remains the same. This is not surprising. As others have noted, the "originalist" Jus-

Church-State Test Case, 42 DRAKE L. REV. 343, 382 (1993). On the other hand, the conclusion offered here, that judges find it necessary to distort the evidence in order to reach the results they want, suggests that originalism is not in fact infinitely malleable, if its methods are honestly applied.

3 Its claims are elaborated in Part II, infra. 
tices are only opportunistically originalist. ${ }^{4}$ When original meaning does not support the result they want to reach, they tend to ignore it, making it difficult to take their professions of originalism seriously. ${ }^{5}$ Here, though, I set that aside and consider their "originalist" interpretations of the Establishment Clause on the merits. I begin by noting the political context in which they arise. I then examine their arguments.

\section{A. Originalism, Orthodoxy, and the Republican Party}

The fundamental claim upon which most of the self-styled "originalists" converge is that the Establishment Clause does not prohibit government from endorsing religion generally, so long as it does not discriminate among religions. (It later became clear that this meant that government could endorse theism, and perhaps more specific theological claims if these were shared by the major monotheistic religions.) The claim was stated succinctly by Attorney General Edwin Meese III, in his famous 1985 ABA speech calling for "a jurisprudence of original intention." Meese claimed that the original intention was solely

to prohibit Congress from establishing a national church. The belief was that the Constitution should not allow Congress to designate a particular faith or sect as politically above the rest. But to argue, as is popular today, that the Amendment demands strict neutrality between religion and irreligion would have struck the founding generation as bizarre. The purpose was to prohibit religious tyranny, not to undermine religion generally. ${ }^{7}$

\footnotetext{
${ }^{4}$ See, e.g., Erwin Chemerinsky, It's Still the Kennedy Court, 11 GREEN BAG 2d 427, 429-31 (2008) (noting the dubious originalist credentials of Scalia's Second Amendment reasoning); Ira C. Lupu, Employment Division v. Smith and the Decline of Supreme-Court Centrism, 1993 B.Y.U. L. REv. 259, 260 ("Justice Scalia, the author of [Employment Division v. Smith, 494 U.S. 872 (1990),] claims to be an originalist. Smith shows no signs, however, of any such orientation; the Court's opinion totally ignores both the text and history of the Free Exercise Clause." (footnote omitted)); Gene R. Nichol, Justice Scalia and the Printz Case: The Trials of an Occasional Originalist, 70 U. Colo. L. REV. 953, 969-71 (1999) (arguing that, in cases involving takings, free exercise, standing, and affirmative action, "Justice Scalia departs radically from his chosen theory when it suits his fancy"); Eric J. Segall, A Century Lost: The End of the Originalism Debate, 15 CONST. Comment. 411, 427-28 (1998) (noting that Justice Scalia's "votes to overturn flag burning laws, hate speech laws, and affirmative action programs cannot be reconciled with a strictly originalist approach to constitutional interpretation"). Thanks to Thomas Colby for directing me to most of these citations.

${ }^{5}$ The disingenuousness is particularly striking in Parents Involved in Community Schools v. Seattle School Dist. No. 1, 127 S. Ct. 2738 (2007), in which the majority, including all of the "originalist" justices, declined even to discuss the massive evidence, presented to them in the briefs, that race-conscious means of achieving integration were consciously adopted by the Framers of the Fourteenth Amendment. See Brief of Historians as Amici Curiae in Support of Respondents, Parents Involved in Community Schools v. Seattle School Dist. No. 1, 127 S. Ct. 2738 (2007) (No. 05-908 \& 05-915), 2006 WL 2922647.

${ }^{6}$ Edwin Meese III, Speech Before the American Bar Association (July 9, 1985), in ORIGINALISM: A QUARTER-CENTURY OF DEBATE 52 (Steven G. Calabresi ed., 2007).

${ }^{7} I d$.
} 
Meese's position is remarkable, first of all, for its claim that "the founding generation" would have rejected as "bizarre" propositions that were in fact endorsed by Jefferson and Madison. Doubtless the two of them were more strictly separationist than most of their colleagues, but these complexities disappear in Meese's simple statement.

Deeper confusions lie in the easy assumption that the denial of state support "undermines" religion. If this is true, then neutrality between Protestantism and Catholicism undermines Protestantism; neutrality between Presbyterianism and Episcopalianism undermines Presbyterianism, and so forth. Religion, as Meese imagines it, yearns for the state's embrace and is undermined without it. The idea that state support corrupts religion-an idea embraced, not only by Jefferson and Madison, but by Roger Williams, Milton, Locke, Elisha Williams, Backus, Leland, and Adam Smith ${ }^{8}$ - never occurs to Meese. ${ }^{9}$ Meese cites no evidence at all for his claim. To be fair, Meese is not a historian. He is a politician. ${ }^{10}$ It is worth pausing to note just how politically convenient the claim was.

Something unusual in American history happened to religion in the 1970s, just before Meese and the other Reagan men took political power. The character of American religious divisions shifted. The divide between Protestants, Catholics, and Jews, once so important, had lost its salience. New controversies arose over abortion, gay rights, funding for the arts, child care policy, the roles of the sexes, and the place of traditional values in education, especially in sex education. The common thread in these debates, James Davison Hunter observes, is the cleavage between orthodox and progressive worldviews. Orthodoxy is characterized by its adherents' commitment to an external, definable, and transcendent authority. Progressivism, on the other hand, tends to take human well-being as the ultimate standard by which moral judgments and policy decisions are grounded, and

\footnotetext{
${ }^{8}$ See Andrew Koppelman, Corruption of Religion and the Establishment Clause, 50 WM. \& MARY L. REV. (forthcoming 2009).

${ }^{9}$ It also escapes Justice Kennedy, who has claimed that strict separation of church and state "would require government in all its multifaceted roles to acknowledge only the secular, to the exclusion and so to the detriment of the religious." County of Allegheny v. ACLU, 492 U.S. 573, 657 (1989) (Kennedy, J., concurring in the judgment in part and dissenting in part). This "detriment" is just what the religious proponents of disestablishment were hoping for.

${ }^{10}$ So were John Roberts and Samuel Alito, who were then Reagan Administration staffers, and who expressed similar views. See Memorandum from John G. Roberts to Fred F. Fielding 2 (June 4, 1985), available at http://www.washingtonpost.com/wp-srv/nation/documents/roberts/Box48-JGR-School Prayer1.pdf (memorandum written by Chief Justice Roberts while serving in President Reagan's Office of White House Counsel, approving of then-Justice Rehnquist's attempt to "revolutionize" Establishment Clause jurisprudence by adopting the theory that the government may engage in the nonsectarian endorsement of religion); Samuel Alito, Non-Career Appointment Form 3 (Nov. 15, 1985), available at http://www.law.com/pdf/dc/alitoDOJ.pdf (application for a job as deputy assistant attorney general for the Reagan Administration, in which Justice Alito wrote that in college he "developed a deep interest in constitutional law, motivated in large part by disagreement with Warren Court decisions, particularly in the areas of criminal procedure, the Establishment Clause, and reapportionment").
} 
to treat any moral truth as a human construction that is always subject to reevaluation in light of experience. ${ }^{11}$

In these new controversies, conservative Christians and Jews frequently joined together against progressives of both faiths. It became reasonable to hope that the Republicans could capture the Jewish vote for the first time since the 1920s. ${ }^{12}$ (Compare the bitterly controversial Presidential candidacy of Catholic John F. Kennedy in 1960 with the non-issue of Jewish, but clearly orthodox in Hunter's sense, Vice-Presidential candidate Joseph Lieberman in 2000.) The traditionalists became an important constituency of the Republican party. ${ }^{13}$ While they differed over many things, they could agree on the importance of authority, notably symbolized by the invocation of God. What could be more congenial to this coalition than a constitutional rule that equated the views of the traditionalists with national identity, while holding that those most distant from the traditioanlists' revered authority were not full members of the political community?

\section{B. Rehnquist}

The rule proposed by Meese had been declared a month earlier in a dissenting opinion by then-Justice William Rehnquist, relying on very recent scholarly claims by Robert Cord:

The Framers intended the Establishment Clause to prohibit the designation of any church as a "national" one. The Clause was also designed to stop the Federal Government from asserting a preference for one religious denomination or sect over others. Given the "incorporation" of the Establishment Clause as against the States via the Fourteenth Amendment in Everson, States are prohibited as well from establishing a religion or discriminating between sects. As its history abundantly shows, however, nothing in the Establishment Clause requires government to be strictly neutral between religion and irreligion, nor does that Clause prohibit Congress or the States from pursuing legitimate secular ends through nondiscriminatory sectarian means. ${ }^{14}$

\footnotetext{
11 See James Davison Hunter, Culture Wars: The Struggle to Define America (1991).

12 See Herbert L. Solomon, The Republican Party and the Jews, 37 JUDAISM 276 (1988) (predicting a shift in Jewish support away from Democratic and toward Republican candidates in the 1988 election).

${ }^{13}$ See Geoffrey Layman, The Great Divide: Religious and Cultural Conflict in AMERICAN PARTY POLITICS 307-26 (2001); ROBERT WUTHNOW, THE RESTRUCTURING OF AMERICAN RELIGION: SOCIETY AND FAITH SINCE WORLD WAR II 218-22 (1988). The effect has become more pronounced over time. In the 2004 presidential election, those attending church more than once a week voted for Bush by a margin of 65 percent to 35 percent, while those who never attend church were almost the inverse: 36 percent to 62 percent. 69 percent of Orthodox Jews voted for Bush, while only 23 percent of Conservative Jews and 15 percent of Reform Jews voted for him. Bush won 40 percent of the votes of Jews attending synagogue on a weekly basis, compared to 18 percent of those who rarely or never attend. Jay Lefkowitz, The Election and the Jewish Vote, CommENT., Feb. 2005, at 61, 64.

14 Wallace v. Jaffree, 472 U.S. 38, 113 (1985) (Rehnquist, J., dissenting). Rehnquist cites RoBERT Cord, SEPARATion OF ChuRCh AND State (1982). Id. at 104. If Supreme Court Justices are going to
} 
On this basis, Justice Rehnquist would have permitted a "generalized 'endorsement' of prayer." 15 Justice Thomas followed this line for a time, finding "much to commend" in "the view that the Framers saw the Establishment Clause simply as a prohibition on governmental preferences for some religious faiths over others." 16

Subsequent historical scholarship showed, however, that the nonpreferentialist interpretation of the First Amendment was mistaken. The First Congress considered and rejected at least four drafts of the amendment that explicitly would have adopted the nonpreferentialist view. Nor does the admittedly sparse legislative history offer much support for the position. No state offered nonpreferential aid to churches. Such aid was only seriously proposed in Maryland and Virginia, where it was rejected after much public debate in 1785 and 1786. Aid to more than one church was offered in some New England states, but those systems were in practice preferential and produced bitter division. There were also a variety of practices that endorsed and supported a generalized Protestantism, but these were uncontroversial in a uniformly Protestant country, and no one appears to have given much thought to their constitutional status. And, of course, state preference for Protestantism is not nonpreferentialism. ${ }^{17}$

In 1992, Michael McConnell observed that Chief Justice Rehnquist "has not mentioned" his nonpreferentialism theory since he wrote his opinion in Wallace in 1985, and that he "may have abandoned it." ${ }^{18}$ Rehnquist never retracted his view, but to his credit, he became quiet about it when it became clear that it was wrong. On the other hand, he did not change his position, but joined opinions by Scalia that proposed the same interpretation of the Establishment Clause on a different basis.

propose to revolutionize the law on the basis of scholarship purporting to reveal the Constitution's original meaning, it would be prudent for them to wait a while to see how the scholarship is received. Cord's book was subjected to devastating critique within a few years of its publication. See infra note 17.

15 Id. at 114 .

${ }^{16}$ See Rosenberger v. Rector \& Visitors of Univ. of Va., 515 U.S. 819, 855 (1995) (Thomas, J., concurring).

17 See Thomas J. Curry, The First Freedoms: Church and State in America to the Passage of the First Amendment (1986); LeOnard W. LeVy, The Establishment Clause: Religion AND the First AMENDMENT (2d ed. 1994); Douglas Laycock, "Nonpreferential" Aid to Religion: A False Claim About Original Intent, 27 WM. \& MARY L. REV. 875 (1986). There was cause for doubt even before Rehnquist wrote his opinion. See Mark V. Tushnet, Book Review, 45 LA. L. REV. 175, 175 (1984) (concluding that Cord's book "is a work of crank constitutional law").

18 Michael W. McConnell, Religious Freedom at a Crossroads, 59 U. CHI. L. REV. 115, 145 (1992). There is disagreement about how strong the argument was when Rehnquist made it. McConnell claims that Rehnquist relied on "seemingly powerful evidence of the original understanding," which was refuted by "more complete historical research." Id at 146. Laycock, on the other hand, writes that "[t]he prominence and longevity of the nonpreferential aid theory is remarkable in light of the weak evidence supporting it and the quite strong evidence against it." Laycock, supra note 17, at 877. 


\section{Scalia}

The nonpreferentialist theme was picked up intact by Justice Scalia in 1987 in Edwards v. Aguillard, a case involving the teaching of "creation science" in the public schools. ${ }^{19}$ He proposed that the Court abandon the requirement that a law have a secular purpose. Scalia is the Court's most strident originalist, ${ }^{20}$ but in Edwards, unlike Rehnquist in Wallace, he offered no evidence of original intent at all. Instead, he proposed to modify the rule, like a good common law judge, because it was allegedly unworkable. $^{21}$

Five years later, however, in Lee v. Weisman, he became an originalist again. He proposed to uphold a prayer at a public school graduation entirely on the basis of history:

Justice Holmes' aphorism that "a page of history is worth a volume of logic" applies with particular force to our Establishment Clause jurisprudence. As we have recognized, our interpretation of the Establishment Clause should "compor[t] with what history reveals was the contemporaneous understanding of its guarantees." "[T]he line we must draw between the permissible and the impermissible is one which accords with history and faithfully reflects the understanding of the Founding Fathers." "[H]istorical evidence sheds light not only on what the draftsmen intended the Establishment Clause to mean, but also on how they thought that Clause applied" to contemporaneous practices. Thus, "[t]he existence from the beginning of the Nation's life of a practice, [while] not conclusive of its constitutionality ... [,] is a fact of considerable import in the interpretation" of the Establishment Clause.

The history and tradition of our Nation are replete with public ceremonies featuring prayers of thanksgiving and petition. ${ }^{22}$

The "originalism" here is of a very limited kind. No theory of the Establishment Clause follows from Scalia's premise. History is a purely negative source. As Kyle Duncan has written, "[t]raditions reflected in longstanding and persisting government practice generally tell Scalia what a constitutional provision was not originally designed to do." ${ }^{23}$ But then, what does Scalia think the Establishment Clause means? Scalia offered the following rule as an interpretation of the clause:

${ }^{19}$ Edwards v. Aguillard, 482 U.S. 578, 636-40 (1987) (Scalia, J., dissenting).

${ }^{20}$ See, e.g., Antonin Scalia, Originalism: The Lesser Evil, 57 U. CIN. L. REV. 849 (1989).

${ }^{21}$ For a critique of the unworkability claim, see Andrew Koppelman, Secular Purpose, 88 VA. L. REV. 87 (2002)

22 Lee v. Weisman, 505 U.S. 577, 632-33 (1992) (Scalia, J., dissenting) (citations omitted). For a similar catalogue of American ceremonial recognitions of religion, see McCreary County v. ACLU, 545 U.S. 844, 885-89 (2005) (Scalia, J., dissenting).

23 Kyle Duncan, Bringing Scalia's Decalogue Dissent Down from the Mountain, 2007 UTAH L. REV. 287, 304. 
[O]ur constitutional tradition . . rule[s] out of order government-sponsored endorsement of religion ... where the endorsement is sectarian, in the sense of specifying details upon which men and women who believe in a benevolent, omnipotent Creator and Ruler of the world are known to differ (for example, the divinity of Christ). ${ }^{24}$

This formulation offers many puzzles. First, Scalia does not cite a single historical source endorsing it. He shows that historical practice is consistent with it, but that is hardly the same thing as showing that anyone thought that it was a constitutional requirement. ${ }^{25}$ In fact, the common ground at the time of the Framing was not theism, but Protestantism. ${ }^{26} \mathrm{Sec}-$ ond, it is not clear how this rule follows from any of the purposes of the Establishment Clause. Scalia says nothing about those purposes. One reads his opinions in vain for any account of what the point was of having an Establishment Clause in the first place.

More recently, in McCreary County v. ACLU, ${ }^{27}$ dissenting from a decision barring one ceremonial display of the Ten Commandments, Scalia frankly acknowledged that ceremonial theism would entail "contradicting the beliefs of some people that there are many gods, or that God or the gods pay no attention to human affairs." 28 The Commandments "are assuredly a religious symbol, but they are not so closely associated with a single religious belief that their display can reasonably be understood as preferring one religious sect over another. The Ten Commandments are recognized by Judaism, Christianity, and Islam alike as divinely given." 29 Justice Stevens objected that "[t]here are many distinctive versions of the Decalogue, ascribed to by different religions and even different denominations within a particular faith; to a pious and learned observer, these differences may be of

\footnotetext{
${ }^{24}$ Lee, 505 U.S. at 641 . It is unclear how this position can be reconciled with his vote in favor of opening football games with a Christian prayer in Santa Fe Independent School District v. Doe, 530 U.S. 290 (2000) (Rehnquist, C.J., dissenting) (joined by Scalia \& Thomas, JJ.), and in favor of a statesponsored Christian crèche in County of Allegheny v. ACLU, 492 U.S. 573 (1989) (Kennedy, J., concurring in the judgment and dissenting in part) (joined by Rehnquist, C.J., White \& Scalia, JJ.).

${ }^{25}$ See Thomas Colby, A Constitutional Hierarchy of Religions? Justice Scalia, the Ten Commandments, and the Future of the Establishment Clause, 100 Nw. U. L. REV. 1097, 1126-38 (2006).

${ }^{26}$ See CURRY, supra note 17, at 123-24 ("They did not oppose a particular religion to religion in general in the sense of Protestantism, Catholicism, Judaism, or any other faith. Rather, they opposed a particular Protestant denomination to Protestantism in general, which latter they did not equate with an establishment.... [T]he notion of prayer and worship based on the Bible that was accepted by all Protestants did not amount to a general establishment, but constituted an essential foundation of civilization. Such others as Catholics or Jews did not impinge sufficiently on their lives to challenge that assumption.”).

27545 U.S. 844.

${ }^{28}$ Id. at 893 (Scalia, J., joined by Rehnquist, C.J., and Thomas, J., dissenting).

${ }^{29}$ Id. at 909. There is a delicious ambiguity, which I will not pursue further here, about what it means to be "associated with a single religious belief." If the Ten Commandments are not so associated, then neither is the divinity of Christ, since Protestants and Catholics who violently disagree on many religious issues are nonetheless in agreement about that.
} 
enormous religious significance." "30 Scalia-here joined by Rehnquist, Thomas, and Kennedy - retorted: "The sectarian dispute regarding text, if serious, is not widely known. I doubt that most religious adherents are even aware that there are competing versions with doctrinal consequences (I certainly was not)." ${ }^{31}$ Justice Scalia thus envisions a role for the Court in which it decides which articles of faith are sufficiently widely shared to be eligible for state endorsement (and in which determinedly uneducable judicial ignorance is a source of law!). Evidently, the state may endorse any religious proposition so long as that proposition is - or is believed by a judge unacquainted with doctrinal niceties to be-a matter of agreement between Judaism, Christianity, and Islam. It would, for instance, be permissible for the state to declare that Gabriel is one of the most important archangels. The interpretation of the Establishment Clause would then depend on the further development of the Moslem idea of the People of the Book-those who have received a revelation that is deemed, formerly by the Koran, now by the Supreme Court - to be reliably from God. The originalist credentials of that particular idea are pretty bad. The United States at the time of the Framing was quite hostile to Moslem theology. ${ }^{32}$

If there was a theological consensus at the time of the Framing, it looked nothing like the generalized monotheism that Scalia embraces. At that time, "[a]ll but two [states] had religious tests for office, disqualifying Jews, Unitarians, and agnostics. Some states even refused to enfranchise them, so they could not vote." ${ }^{33}$ In most of the United States, only Protestants could hold office, and Delaware restricted office to Trinitarians. ${ }^{34}$

Scalia's vision of state incompetence is limited only to certain theological propositions. The state must not adjudicate the divinity of Christ. But it is only disagreement among monotheists that the state must keep its hands off. It can authoritatively and reliably pronounce its views on the question of theism. ${ }^{35}$

\footnotetext{
${ }^{30}$ Van Orden v. Perry, 545 U.S. 677, 717-18 (2005) (Stevens, J., dissenting) (citing Steven Lubet, The Ten Commandments in Alabama, 15 Const. COMMENT. 471, 474-476 (1998)).

${ }^{31}$ McCreary, 545 U.S. at 909 n.12 (Scalia, J., joined by Rehnquist, C.J., Kennedy, J., and Thomas, J., dissenting).

32 Before 1800, there was "a well-established tradition" of "citing the similarities between an opponent's views and the 'beliefs' of Islam as a means to discredit one's adversaries." Thomas S. Kidd, "Is It Worse to Follow Mahomet than the Devil?" Early American Uses of Islam, 72 CHURCH HIST. 766, 766 (2003); see also ROBERT J. ALLISON, THE CRESCENT OBSCURED: THE UNITED STATES AND THE MUSLIM WORLD, 1776-1815, at 35-59 (1995) (detailing the use of a negative portrayal of Islam and the Muslim world by politicians and thinkers at the time of the Framing); Denise A. Spellberg, Could a Muslim Be President? An Eighteenth-Century Constitutional Debate, 39 EIGHTEENTH-CENTURy STUD. 485 (2006) (contrasting the rhetorical use of Muslims by Federalists and Anti-Federalists).

33 LEVY, supra note 17 , at 77.

${ }^{34}$ Gerard V. Bradley, The No Religious Test Clause and the Constitution of Religious Liberty: A Machine That Has Gone of Itself, 37 CASE W. RES. L. REV. 674, 681-83 (1987).

${ }^{35}$ For a similar criticism of the nonpreferentialist position, see Lee v. Weisman, 505 U.S. 577, 617 (1992) (Souter, J., concurring) (noting that, because many religious Americans are not theists, a non-
} 
Scalia's solution departs from Rehnquist's earlier nonpreferentialism, because it unapologetically discriminates among religions. Rehnquist thought that the Establishment Clause forbids "asserting a preference for one religious denomination or sect over others." 36 Justice Scalia once agreed: "I do not think that the Establishment Clause prohibits formally established 'state' churches and nothing more. I have always believed, and all my opinions are consistent with the view, that the Establishment Clause prohibits the favoring of one religion over others." ${ }^{37}$ Not all religions involve a belief in "a benevolent, omnipotent Creator and Ruler of the world." ${ }^{38}$ Scalia's formulation does discriminate among religions. Christians, Jews, and Moslems are in; Hindus, Buddhists, and atheists are out. The outs are a lot of people.

Thomas Colby has argued that Scalia has adopted the astounding position that the Establishment Clause itself discriminates among religions: state endorsement of polytheism or atheism would violate the clause, but state endorsement of biblical monotheism does not. ${ }^{39}$ Kyle Duncan has responded that Scalia is using generalized monotheism as a baseline for what is constitutionally permitted but is not committed to invalidating other endorsements of religious belief that are not monotheistic. Scalia's traditionalism, Duncan observes, is "a 'one-way ratchet'-that is, a method that tends to use tradition negatively (to say what practices ambiguous constitutional guarantees do not restrain) and not positively (to say what practices ambiguous constitutional guarantees forbid)." 40

This "one-way ratchet" approach relies on no theory of the meaning or purpose of the Establishment Clause. Scalia's claim is that whatever the Establishment Clause means, it cannot apply to a practice of which the Framers knew and approved. The argument is essentially, "I have no idea

preferentialist "would still need to explain why the government's preference for theistic religion is constitutional").

${ }^{36}$ Wallace v. Jaffree, 472 U.S. 38, 113 (1985) (Rehnquist, J., dissenting).

${ }^{37}$ Bd. of Educ. of Kiryas Joel Vill. Sch. Dist. v. Grumet, 512 U.S. 687, 748 (1994) (Scalia, J., dissenting). Again, it is not clear what "one religion" means here.

${ }^{38}$ Lee, 505 U.S. at 641 (1992) (Scalia, J., dissenting). The Court held long ago that the Establishment Clause forbids government to "aid those religions based on a belief in the existence of God as against those religions founded on different beliefs." Torcaso v. Watkins, 367 U.S. 488, 495 (1961). The Court noted that "[a]mong religions in this country which do not teach what would generally be considered a belief in the existence of God are Buddhism, Taoism, Ethical Culture, Secular Humanism and others." Id. at $495 \mathrm{n} .11$. To say that Buddhism rejects theism is something of an overstatement. While the historical Buddha had no interest in theological questions, some forms of Buddhism make theological claims, sometimes assigning divine status to Buddha himself. For a general overview of these issues, see Masao Abe, Buddhism, in Our Religions 69-137 (Arvind Sharma ed., 1993). Hinduism is only the most prominent of many polytheistic religions. There are, concededly, monotheistic interpretations of Hinduism, but not all Hindus subscribe to these interpretations.

${ }^{39}$ Colby, supra note 25, at 1102.

${ }^{40}$ Duncan, supra note 23, at 327 (quoting A.C. Pritchard \& Todd Zywicki, Finding the Constitution: An Economic Analysis of Tradition's Role in Constitutional Interpretation, 77 N.C. L. REV. 409, 424-25 (1999)). 
what this provision means. But whatever it means, it can't prohibit this, because the Framers approved of it." This is a distinctive kind of originalism, and it ought to have a name. ${ }^{41}$ Call it "I Have No Idea Originalism."

Colby's reading attributes to Scalia a claim of principle. Duncan's implicit premise is that this is mistaken. If Duncan is right, then Colby's mistake is understandable. Judges interpreting legal provisions are generally understood to be making claims about what those provisions mean. According to Duncan, however, Scalia was doing nothing of the sort. Scalia has made no claims about the meaning of the Establishment Clause because he hasn't the foggiest notion what it means. ${ }^{42}$ Duncan's interpretation of Scalia implies that Colby has misinterpreted Scalia out of an excess of charity. ${ }^{43}$

There are several difficulties with "I Have No Idea Originalism." One is that it produces results that modern interpreters are likely to be uncomfortable with. A structurally identical argument was made on behalf of laws mandating segregated schools, or prohibiting interracial marriage: the Framers knew and approved of such laws, therefore the Fourteenth Amendment, whatever it means, cannot prohibit that. ${ }^{44}$ The same argument might be made to show that the Free Speech Clause permits a law criminalizing criticism of incumbent officeholders. Congress enacted just such a law, less than a decade after the First Amendment was adopted, in the Sedition Act of 1798, which made it a crime to write about Congress or the

41 It does not appear in the otherwise very useful taxonomy of originalisms in Colby and Smith. See Colby \& Smith, supra note 2, pt. I. On the other hand, the basic methodological move, and its fundamental lack of principle, are noted in Thomas B. Colby, The Federal Marriage Amendment and the False Promise of Originalism, 108 COLUM. L. REV. 529, 573-74 (2008).

42 Neither does Duncan:

At most, Scalia would be saying that religious acknowledgments that diverge from historical standards (for instance, a Christian symbol, or Islamic language, or a Buddhist text) would not be the easy Establishment Clause cases that a generic monotheism presents. What "test" Scalia might devise to assess these harder cases he does not say, and it is beyond the scope of this Article to devise one.

Duncan, supra note 23 , at 342.

43 On the other hand, it is not clear that Duncan's interpretation of the evidence fits the data better than Colby's. "There are a few passages in Scalia's dissent that, if read out of context and divorced from Scalia's interpretative methodology and overall jurisprudence, might support" Colby's reading, Duncan admits. Id. at 324. In other words, there are passages in Scalia that do appear to be articulating a rule, albeit one that the Framers never articulated and that Duncan implicitly concedes is indefensible.

44 See RAOUl BERGER, GOVERnMENT By Judiciary: THE TRANSFORMATION OF THE FourTEENTH AMENDMENT 117-33, 161-63 (1977); Alfred Avins, Anti-Miscegenation Laws and the Fourteenth Amendment: The Original Intent, 52 VA. L. REV. 1224 (1966). Duncan claims that Fourteenth Amendment cases are distinctive, observing that "Scalia sees the Equal Protection Clause as having 'counter-historical' content- that is, as designed to invalidate certain historical practices that might otherwise claim the status of tradition." Duncan, supra note 23, at 315 (quoting Pac. Mut. Life Ins. Co. v. Haslip, 499 U.S. 1, 38 (1991) (Scalia, J., concurring)). The Establishment Clause, however, is no less counter-historical than the Equal Protection Clause. Both provisions are reactions against certain specific historical practices. 
President "with intent to defame" or "to excite against them ... the hatred of the good people of the United States." 45

The deeper problem is that "I Have No Idea Originalism" does not even try to interpret the Constitution. It does not attempt to state the principle for which the disputed constitutional provision stands. Scalia might argue that original practice cannot determine the meaning of these clauses, but it can eliminate some proposed interpretations, those inconsistent with the original practices. As we have just seen, however, the procedure for eliminating even those interpretations is question-begging. The fact that someone in the Founding generation did something does not prove that it was constitutionally permissible even then. You have to say what the clause means before you can tell whether it has been violated. ${ }^{46}$

The defenders of the miscegenation laws did better than Scalia in this respect. In the 1883 case of Pace v. Alabama,${ }^{47}$ the Supreme Court upheld the constitutionality of miscegenation laws. The statute in question in Pace prescribed penalties for interracial sex that were more severe than those imposed for adultery or fornication between persons of the same race. The Court unanimously rejected the equal protection challenge to the statute, denying that the statute discriminated on the basis of race:

[The section prohibiting interracial sex] prescribes a punishment for an offence which can only be committed where the two sexes are of different races. There is in neither section any discrimination against either race. . . Whatever discrimination is made in the punishment prescribed in the two sections is directed against the offence designated and not against the person of any particular color or race. The punishment of each offending person, whether white or black, is the same. ${ }^{48}$

The Pace Court did not embrace "I Have No Idea Originalism." It had a principle upon which it relied: the Equal Protection Clause prohibits laws that treat the races differently. Miscegenation laws, the Court held, do not violate that principle. ${ }^{49}$

The trouble with the Pace Court's reasoning, of course, is that it is entirely decoupled from the underlying purposes of the Equal Protection Clause.

\footnotetext{
45 The Sedition Act, ch. 74, 1 Stat. 596 (1798).

${ }^{46}$ For a similar argument by a careful originalist, see Michael W. McConnell, On Reading the Constitution, 73 CORNELL L. REV. 359, 362-63 (1988).

47106 U.S. 583 (1883).

${ }^{48} I d$. at 585.

49 It may sound to you like a silly argument, but for a long time courts have rejected claims that discrimination against gay people is sex discrimination on the basis of the identical logic: men who have sex with men and women who have sex with women are treated the same, therefore there is no sex discrimination. See, e.g., In re Marriage Cases, 183 P.3d 384, 438 (Cal. 2008) (rejecting sex discrimination argument, but upholding claim for same-sex marriage on other grounds). For a critique, see Andrew Koppelman, Defending the Sex Discrimination Argument for Lesbian and Gay Rights: A Reply to Edward Stein, 49 UCLA L. REV. 519 (2001); Andrew Koppelman, Why Discrimination Against Lesbians and Gay Men is Sex Discrimination, 69 N.Y.U. L. REV. 197 (1994).
} 
The later Plessy v. Ferguson decision, upholding racial segregation statutes (relying in part on the authority of Pace), at least concedes that it would cut against a law's constitutionality if it were true that the law "stamps the colored race with a badge of inferiority." there is an Equal Protection Clause, though it implies that the concern is not with the subordination of groups, but with a certain kind of classification. (In this it resembles the present Court. $)^{51}$ It is, then, unsurprising that it was ultimately overruled when the Court noticed that miscegenation laws were "measures designed to maintain White Supremacy," ${ }^{2}$ and that this purpose "violates the central meaning of the Equal Protection Clause."

Jack Balkin observes that when the text of the Constitution proposes a vague principle, like equal protection or nonestablishment, that principle must be cashed out in terms of subsidiary or underlying principles. History can help determine what these principles are. Contemporaneous statements of principle, and the general problems that the provision sought to address, are both pertinent. "The principles underlying the text should be at roughly the same level of generality as the text (understood to include any generally recognized terms of art). If the text uses general language, the underlying principles that support and explain the text should as well." ${ }^{54}$ This is because the Framers should be presumed to know what they are doing if they use very abstract language. "Absent strong evidence to the contrary, we assume that people choose general language if they want to endorse general principles, and more specific language if they want to commit themselves to narrower principles." ${ }^{, 55}$

So with the Establishment Clause, our task is to discern the principle for which the provision stands. The proper originalist formulation is that of a Supreme Court Justice who never proclaimed himself an originalist, William Brennan, who wrote in 1963 that the Court should ask whether challenged practices "threaten those consequences which the Framers deeply feared; whether, in short, they tend to promote that type of interdependence between religion and state which the First Amendment was designed to

\footnotetext{
${ }^{50}$ Plessy v. Ferguson, 163 U.S. 537, 551 (1896). "If this be so," the Court concluded, "it is not by reason of anything found in the act, but solely because the colored race chooses to put that construction upon it." Id. Charles Black observes that "the Plessy Court clearly conceived it to be its task to show that segregation did not really disadvantage the Negro, except through his own choice." Charles L. Black, Jr., The Lawfulness of the Segregation Decisions, 69 YALE L.J. 421, 422 (1960).

${ }^{51}$ See supra note 5.

52 Loving v. Virginia, 388 U.S. 1, 11 (1967).

53 Id. at 12 .

${ }^{54}$ Jack M. Balkin, Original Meaning and Constitutional Redemption, 24 CONST. COMMENT. 427, 493 (2007).

${ }^{55}$ Id. The same point was made long ago by Dworkin. See supra note 1.
} 
prevent." 56 The question is what are "those substantive evils the fear of which called for the Establishment Clause of the First Amendment"? ${ }^{57}$

The interpretive rules proposed by Balkin have no particular political valence. ${ }^{58}$ One might use them as a basis for a narrow or a broad understanding of establishment. Even a very narrow understanding of establishment is different from I Have No Idea Originalism. What is remarkable about Scalia's argument in Lee and McCreary is that he offers no principle at all.

\section{Thomas}

Justice Thomas, who also insists on originalism as a formula for constraining judicial discretion, ${ }^{59}$ has flirted with the nonpreferentialist position. ${ }^{60}$ More recently, however, he has suggested that the Establishment Clause does not constrain the states at all. ${ }^{61}$ He cites Akhil Amar's sugges-

\footnotetext{
${ }^{56}$ Sch. Dist. of Abington Twp. v. Schempp, 374 U.S. 203, 236 (1963) (Brennan, J., concurring).

57 Id. at 241 .

${ }^{58}$ Some originalists have challenged another of Balkin's claims-that constitutional principles should not depend on the original expected application of a constitutional provision. John McGinnis and Michael Rappaport have challenged this claim, arguing that interpretation ought to look to original expected application because doing so yields important information about the meaning of the words. John O. McGinnis \& Michael B. Rappaport, Original Interpretive Principles as the Core of Originalism, 24 CONST. COMMENT. 371 (2007). It is not clear whether McGinnis and Rappaport would follow original expected applications in all cases, such as miscegenation and school segregation; they do not discuss these issues. What is clear is that they think that original expected application should guide a choice among general principles. That is already a constraint on original expected application, since some original expected applications might not be justifiable under any principle reasonably attributable to the text. The use of original expected application that they defend is quite different than that of Justice
} Scalia.

On the other hand, Professor McGinnis has criticized an interpretive argument of mine entirely on the basis of original expected application, arguing that abortion could not possibly raise a Thirteenth Amendment issue because the Framers would not have thought it did. John O. McGinnis, Decentralizing Constitutional Provisions Versus Judicial Oligarchy: A Reply to Professor Koppelman, 20 Const. COMMENT. 39, 56 (2003).

${ }^{59}$ See Clarence Thomas, Judging, 45 U. KAN. L. REV. 1, 6 (1996).

${ }^{60}$ See Rosenberger v. Rector \& Visitors of Univ. of Va., 515 U.S. 819, 855 (1995) (Thomas, J., concurring) (noting the scholarship refuting Cord, but stating with almost no explanation that he takes Cord's side of this debate).

${ }^{61}$ The suggestion had appeared in earlier opinions, but had not been pressed very hard. See Zelman v. Simmons-Harris, 536 U.S. 639, 678-80 (2002) (Thomas, J., concurring) (noting that on its face the Establishment Clause places no limit on states, and arguing that, unlike the Federal Government, states "may pass laws that include or touch on religious matters so long as these laws do not impede free exercise rights or any other individual liberty rights"); Lee v. Weisman, 505 U.S. 577, 641 (1992) (Scalia, J., dissenting, joined by Thomas, J., and others) ("The Establishment Clause was adopted to prohibit such an establishment of religion at the federal level (and to protect state establishments of religion from federal interference)."). Thomas endorsed it again in his most recent Establishment Clause opinion, Van Orden v. Perry, 545 U.S. 677, 693 (2005) (Thomas, J., concurring) ("[T]he [Establishment] Clause's text and history "resis[t] incorporation" against the States." (quoting Elk Grove Unified Sch. Dist. v. Newdow, 542 U.S. 1, 42 (2004) (Thomas, J., concurring))). 
tion that, because the clause is not an individual rights provision, it is not incorporable into the Fourteenth Amendment. ${ }^{62}$ However, he ignores Amar's claim that religious classifications may violate equal protection:

As strange as it sounds, an incorporated Establishment Clause prohibits exactly what the Establishment Clause protected-state practices that pertain to "an establishment of religion." At the very least, the burden of persuasion rests with anyone who claims that the term took on a different meaning upon incorporation. ${ }^{63}$

He suggests that the Court's 1962 and 1963 cases invalidating classroom prayer and Bible reading were wrongly decided. ${ }^{64} \mathrm{He}$ invites litigants to bring about a revolution in Establishment Clause law: "I would welcome the opportunity to consider more fully the difficult questions whether and how the Establishment Clause applies against the States." ${ }^{65}$

Thomas is following a respectable line of scholarship. This scholarship argues that the Establishment Clause did not enact any principle of religious freedom at all, but merely enacted a jurisdictional boundary between the states and the federal government, whereby the federal government had no power either to establish a religion or to eliminate state establishments. This claim has been extensively debated, ${ }^{66}$ and it is a possible reading of the textual language, although no Framer ever expressly endorsed it. ${ }^{67}$

Even if one accepts the claim, however, it does not mean that the Court was mistaken in finding that a nonestablishment principle is binding on the states in Everson and its progeny. The pertinent intention is not that of the Framers of the First Amendment, but the Framers of the Fourteenth, which is the source of any constraint that is now imposed on the states. This is the familiar problem of incorporation of the Bill of Rights. ${ }^{68}$

Kurt Lash has shown that the Framers of the Fourteenth Amendment certainly intended to apply the establishment norm to the states. Freedom from established religion was understood to be an aspect of individual freedom of conscience: "By 1868, the (Non)Establishment Clause was under-

\footnotetext{
${ }^{62}$ Elk Grove Unified Sch. Dist. v. Newdow, 542 U.S. 1, 52 n.4 (2004) (Thomas, J., concurring in the judgment), citing AKHIL REED AMAR, THE BILl OF RightS: CREATION AND RECONSTRUCTION 25354 (1998). For a critique of Amar, see Andrew Koppelman, Akhil Amar and the Establishment Clause, 33 U. RICH. L. REV. 393 (1999).

${ }^{63}$ Elk Grove, 542 U.S. at 51 (Thomas, J., concurring in the judgment).

${ }^{64} I d$. at 53 (quoting Justice Stewart's dissent in the prayer case, Engel v. Vitale, 370 U.S. 421, 445 (1962))

${ }^{65} I d$. at 51 .

${ }^{66}$ For a brief summary of the literature, see Steven D. Smith, The Jurisdictional Establishment Clause: A Reappraisal, 81 Notre DAME L. ReV. 1843, 1844 (2006).

${ }^{67}$ Steven K. Green, Federalism and the Establishment Clause: A Reassessment, 38 CREIGHTON L. REV. 761 (2005); see also Douglas Laycock, Theology Scholarships, the Pledge of Allegiance, and Religious Liberty: Avoiding the Extremes but Missing the Liberty, 118 HARV. L. REV. 155, 240-43 (2004) (noting other flaws in Thomas's originalist argument).

${ }^{68}$ The literature is reviewed in AMAR, supra note 62, at 137-140.
} 
stood to be a liberty as fully capable of incorporation as any other provision in the first eight amendments to the Constitution." ${ }^{69}$

Perhaps Thomas has an answer to the difficulty raised by Lash's scholarship. It is impossible to tell. Thomas ignores Lash and pretends that his work does not exist. Instead, he selectively cites the findings of originalist scholarship that support the result he is inclined to reach-sweeping contrary evidence under the rug-while claiming that he is merely following the intentions of the Framers. ${ }^{70}$

69 Kurt T. Lash, The Second Adoption of the Establishment Clause: The Rise of the Nonestablishment Principle, 27 ARIZ. ST. L.J. 1085, 1154 (1995). For a similar view on the incorporation question, see 2 Kent GREenawalt, Religion and the Constitution: Establishment and FaIRNESS 14-15, 26-39 (2008). Steven D. Smith, one of the most prominent exponents of the jurisdictional interpretation of the Establishment Clause, asks some good questions about Lash. Lash shows that the Framers of the Fourteenth Amendment thought, mistakenly, that the Establishment Clause had more substantive content than the Framers intended. "Did the enactors intend to incorporate their own (mistaken) understanding of the religion clauses?" STEVEn D. SMith, Foreordained FaILURE: THE QUEST FOR A CONSTITUTIONAL PRINCIPLE OF RELIGIOUS FREEDOM 51 (1995). It seems equally possible that the enactors "intended to incorporate the original meaning of the religion clauses, whatever that original meaning was." Id. (emphasis in original). It is impossible to tell which of these the Framers of the Fourteenth Amendment themselves would have preferred. And even if the Amendment includes a nonestablishment norm, its meaning is very different from, and rests on different historical sources than, what has generally been supposed. "Madison and Jefferson, Isaac Backus and John Leland, would be displaced as definers of constitutional religious freedom by John Bingham, Thaddeus Stevens, Charles Sumner, and their contemporaries." Id. at 53. Given the dominance of the "Christian Nation" idea in the mid-nineteenth century, Smith argues, the understanding of the religion clauses that follows from Lash's thesis is likely to be very different from present doctrine, or from what Madison imagined.

Smith overlooks a third possibility: that the Framers of the Fourteenth Amendment understood themselves to be embodying just the kind of ideal of nonestablishment that had animated Madison, and that they were trying to constrain the states, and thus to avoid the evils of alienation and corruption, in just the same way that the original Establishment Clause constrained the federal government. If this is correct-here it can only be a suggestion — then the Court has been right to rely on the thought of Madison, who gave religion far more sustained attention than the Framers of 1868, to work out the meaning of nonestablishment.

More recently, Smith has been more generous to the idea that the Fourteenth Amendment could be a basis for a broad conception of Establishment Clause constraints on the states. Smith, supra note 66.

${ }^{70}$ In fairness to Justice Thomas, a Westlaw "citing references" search of sources citing Lash's article finds that it has only been mentioned in two Supreme Court briefs, and neither addressed the core question of whether the Establishment Clause is jurisdictional. One tried to show that state establishments were no longer protected from federal scrutiny. Brief of National Association of Evangelicals and Union of Orthodox Jewish Congregations of America as Amici Curiae in Support of Petitioners at 2426, Cutter v. Wilkinson (No. 03-9877), 2004 WL 2967824. The other, by selective quotation, misrepresented Lash's principal thesis. Brief on the Merits of Amicus Curiae Pacific Justice Institute at 16, McCreary County, Kentucky v. ACLU of Kentucky (No. 03-1693), 2004 WL 2851010.

On the other hand, it is reasonable to expect Thomas, before proposing a constitutional revolution, to do his basic homework and to familiarize himself with the historical scholarship. He might have begun by more carefully reading Amar's book, on which he placed such reliance, since Amar includes a discussion of Lash's precise findings, although not in the passages Thomas cites. AMAR, supra note 62, at 254-56. The Supreme Court has excellent librarians. Had Justice Thomas asked one of them to find the evidence, he would have gotten Lash's article immediately. 
Thomas has also attributed to the Framers a different view: that a violation of the Establishment Clause requires legal coercion. ${ }^{71}$ His method is essentially the same as Scalia's: he shows that the Framers' behavior was consistent with such a rule. He offers no evidence that any Framer endorsed, or even thought of, that rule. He calls the rule he has invented "the original meaning of the Clause." 72

\section{ESTABLISHMENT OF RELIGION AS A PARADIGM CASE}

What would a sound originalist approach to the Establishment Clause look like?

The role of original meaning is contested in constitutional law. But it is generally agreed that, when a provision is aimed at a specific historical evil, the provision should be read as preventing a recurrence of that evil or others relevantly like it. Of course, there is room for disagreement as to what counts as other evils relevantly like it. When a situation not absolutely identical to that original evil arises, we must decide whether it is relevantly like it. In such a situation, the original meaning won't help us. The prohibition rarely arrives with a rule for its interpretation, and often the Framers had no specific interpretive rule in mind. ${ }^{73}$ When the authors of the First Amendment condemned establishment, Thomas Curry noted, "they had in their minds an image of tyranny, not a definition of a system."

\section{A. The Paradigm Case Method}

Jed Rubenfeld has observed that constitutional interpretation is frequently guided by paradigm cases, which are specific core commitments that are memorialized by the constitutional provisions. An example is the Fourteenth Amendment. The amendment's language is broad, but it was enacted specifically in order to outlaw the Black Codes-laws enacted by white-controlled legislatures after the Civil War that imposed specific legal disabilities on blacks, such as requiring them to be gainfully employed under contracts of long duration, excluding them from occupations other than manual labor, and disabling them from testifying against whites in court. ${ }^{75}$

\footnotetext{
${ }^{71}$ Van Orden v. Perry, 545 U.S. 677, 693-94 (2005) (Thomas, J., concurring). The originalist evidence here likewise has been shown to be weak. See Douglas Laycock, "Noncoercive" Support for Religion: Another False Claim About the Establishment Clause, 26 VAL. U. L. REV. 37 (1991).

72 Van Orden, 545 U.S. at 693.

73 Thus, for example, Leonard Levy has shown that, at the time of the Framing of the Free Speech Clause of the First Amendment, neither James Madison nor anyone else had figured out that the protection of free speech must prevent the state from punishing seditious libel, even though this core meaning of the Clause would shortly be argued by Madison in his critique of the Sedition Act a few years later. LEONARD W. LEVY, EMERGENCE OF A FREE PRESS 321-25 (1985).

74 CURRY, supra note 17, at 211. The Court has similarly observed that the purpose of the Framers of the First Amendment “was to state an objective, not to write a statute." Walz v. Tax Comm'n of the City of New York, 397 U.S. 664, 668 (1970).

75 See TheOdore Brantner Wilson, The Black Codes OF THE SOUth (1965).
} 
Any plausible interpretation of the Fourteenth Amendment must invalidate the Black Codes. More broadly, any interpretation that specifies the more general types of inequality that the amendment forbids must be a chain of inferences from the core commitment represented by the paradigm case. ${ }^{76}$

It is hard to imagine how an originalist could avoid using the paradigm case method in some form, at least in interpreting those constitutional provisions that are aimed at specific evils. For example, the Fourth Amendment's ban on unreasonable searches and seizures should be read in light of the controversies over general searches and writs of assistance before the American Revolution. ${ }^{77}$ The Contract Clause should be read as a response to debtor relief legislation in the $1780 \mathrm{~s}^{78}$ If original meaning is to count at all, then a constitutional provision must be understood to address the very problem that it was designed to remedy.

Unless it states a specific rule, a constitutional provision must also be understood to stand for some principle. That principle must address the very problem that the provision was designed to solve. The principle, however, cannot simply be a rule that addresses that problem and nothing more. If the Framers had intended to address only a specific problem, they could have said so.

\section{B. The Right Establishment Clause Questions to Ask}

The Establishment Clause is a particularly apt candidate for paradigm case interpretation because the core historical wrong that it is intended to bar-an establishment of religion of the kind that existed in England-is specifically named in the text. ${ }^{79}$

Paradigm case reasoning proceeds by "extrapolating general principles from the foundational paradigm cases and applying those principles to the controversy at hand." ${ }^{80}$ With respect to provisions such as the First and Fourteenth Amendments, which prohibit certain government actions, the general principle should give a convincing account of the result in the paradigm case while at the same time properly specifying the kind of evil that the prohibition reaches. The principle should explain what kind of wrong the provision is prohibiting, so that in subsequent controversies it is possible to tell whether the same kind of wrong is or is not occurring.

\footnotetext{
76 Jed Rubenfeld, Freedom and Time: A Theory of Constitutional Self-Government 178-195 (2001). The idea that constitutional provisions should be interpreted in light of paradigm cases is, of course, hardly original with Rubenfeld. See, e.g., Douglas Laycock, Text, Intent, and the Religion Clauses, 4 Notre DAme J.L. Ethics \& PUB. Pol'y 683, 690 (1990). But Rubenfeld lays out the argument with unusual clarity and detail.

77 See Jed Rubenfeld, Revolution By Judiciary: The Structure of American CONSTITUTIONAL LAW 32-33 (2005); Laycock, supra note 76, at 690.

78 See Laycock, supra note 76, at 690.

79 Rubenfeld briefly discusses the interpretation of the Establishment Clause in REvOLUTION BY JUDICIARY, supra note 77, at 29-30.

${ }^{80}$ RUBENFELD, supra note 76, at 191.
} 
In Establishment Clause cases, then, a good originalist judge should ask: (1) why did the Framers think establishment of religion is a bad thing; and (2) is the same bad thing brought about by the challenged action in this case? There will obviously be room for disagreement about both of these issues. The paradigm case method does not decide cases, but it makes clear which questions the judges should ask.

The problem is made more difficult by the need to discern the meaning of the Fourteenth Amendment. ${ }^{81}$ It is clear that the Framers meant to constrain state sponsorship of religion, but it is unclear how they intended to do this. To make matters more difficult, the meaning of nearly every provision of the Bill of Rights that has been incorporated has been held to be exactly the same with respect to the federal government and the states, despite prominent arguments that they ought to be treated differently. ${ }^{82}$

Discerning the original meaning of nonestablishment is obviously far beyond the scope of this Article. It is enough here to show that it is a difficult task, and that the Court's "originalist" judges aren't even trying to do it. But something can be said about what is being ignored in their analysis.

\section{Madison}

The classic description of the pathologies that the Founding generation associated with establishment is James Madison's Memorial and Remonstrance Against Religious Assessments. ${ }^{83}$ Madison was reticent about his own religious beliefs, which were probably some variant of Deism, ${ }^{84}$ but the Memorial and Remonstrance is nonetheless the most useful source of antiestablishment thinking. It was a public document, not a private statement of Madison's views. It presented a synthesis of the anti-establishment views that prevailed in his time, combining religious arguments designed to appeal to Evangelical Christians and secular arguments designed to appeal to Enlightenment Lockeans. ${ }^{85}$ It is unlikely that these groups agreed on anything more than the propositions stated by Madison himself. ${ }^{86}$

\footnotetext{
${ }^{81}$ Justice Thomas evades this difficult problem.

82 See Mark D. Rosen, The Surprisingly Strong Case for Tailoring Constitutional Principles, 153 U. PA. L. REV. 1513 (2005) (arguing against uniformity, and collecting objections by Supreme Court Justices).

83 James Madison, Memorial and Remonstrance Against Religious Assessments (1785), reprinted in THE Mind OF THE Founder: SOURCES OF THE POLITICAL THOUght OF JAMES MADISON 10-11 (Marvin Meyers ed., rev. ed. 1981).

${ }^{84}$ See DAVID L. Holmes, THE FAITHS OF THE Founding FATHERS 91-98 (2006).

85 On the variety of religious and secular positions to which Madison was appealing, see JOHN WitTe, JR., RELIGION AND THE AMERICAN CONSTITUTIONAL EXPERIMENT 21-35 (2d ed. 2005); Thomas E. Buckley, S.J., ChuRch and State in Revolutionary Virginia, 1776-1787 (1977). Vincent Phillip Muñoz observes that "Madison leaves it unclear whether the 'Memorial's' argument is theological, strictly rational, or both." Vincent Phillip Muñoz, James Madison's Principle of Religious Liberty, 97 AM. POL. SCI. REV. 17, 22 n.13 (2003).

${ }^{86}$ Douglas Laycock has explained why an originalist might focus on the Virginia debate in which Madison's was the most important document:
} 
The original meaning of nonestablishment cannot, of course, simply be read off the writings of Madison. Nonetheless, the Memorial and Remonstrance is the most important single datum on that meaning, and it shows us the concerns, prominent at the time of the Framing, that the so-called "originalists" ignore. ${ }^{87}$

Madison objected to the establishment of religion, even the mild nonpreferentialist proposal that he was writing against, for many reasons, of which I will here cite only two. The first is a kind of political alienation. Establishment "degrades from the equal rank of Citizens all those whose opinions in Religion do not bend to those of the Legislative authority." ${ }^{8}$ The second is the corruption of religion itself. Madison argued that the idea "that the Civil Magistrate is a competent Judge of Religious Truth" is "an arrogant pretension falsified by the contradictory opinions of Rulers in all ages." ${ }^{89}$ Madison denounced the idea that religion should be promoted because it is conducive to good citizenship, an idea that we often hear today.

The state debates help show how the concept of establishment was understood in the Framers' generation. Learning how that generation understood the concept may be more informative than the brief and unfocused debate in the House [on the First Amendment. The Senate debate was not recorded]. If the Framers generally understood the concept in a certain way, and if nothing indicates that they used the word in an unusual sense in the first amendment, then we can fairly assume that the Framers used the word in accordance with their general understanding of the concept.

For several reasons, the debates in Virginia were most important. First, the arguments were developed most fully in Virginia. Second, Madison led the winning coalition, and he played a dominant role in the adoption of the establishment clause three years later. Third, the debates in Virginia may have been the best known.

Laycock, supra note 17, at 895; accord SIDNEY E. MEAD, THE LIVELY EXPERIMENT: THE SHAPING OF CHRISTIANITY IN AMERICA 57 (1963).

87 A much narrower reading of the paradigm case might be inferred from the research of Michael McConnell, who notes that the central elements of English establishment were government control over the doctrines, structure, and liturgy of the state church; mandatory attendance at the religious worship services of the state church; public financial support of the state church; prohibition of religious worship in other denominations; the use of the state church for civil functions; and the limitation of political participation to members of the state church. Michael W. McConnell, Establishment and Disestablishment at the Founding, Part I: Establishment of Religion, 44 WM. \& MARY L. REV. 2105, 2131-2181 (2003). But McConnell does not suggest that the Establishment Clause is only violated where one or more of these elements are present. In other writings, it is clear that his own interpretation of the clause is a (far less narrow) extrapolation from the paradigm case. See, e.g., McConnell, supra note 18; Michael W. McConnell, The Problem of Singling Out Religion, 50 DePAul L. REV. 1 (2000); Michael W. McConnell, Why is Religious Liberty the "First Freedom"?, 21 CARDOZO L. REV. 1243 (2000). McConnell's six elements can be mapped directly on to all the modern controversies with even modest efforts to adapt to changed social conditions. See Douglas Laycock, Regulatory Exemptions of Religious Behavior and the Original Understanding of the Establishment Clause, 81 NOTRE DAME L. REV. 1793, 17981801 (2006). A narrow reading of the paradigm case is of course possible, and one might conclude on this basis that school prayer, or even official denunciations of theological error, do not violate the clause. No one on the Court has taken this approach, however, so I will not address it further here. Thanks to Steven D. Smith for pressing me on this issue.

${ }^{88}$ Madison, supra note 83, at 10-11.

89 Id. at 9. 
He felt that this idea was an attempt to "employ Religion as an engine of Civil policy," which he thought "an unhallowed perversion of the means of salvation." 90 Moreover,

experience witnesseth that ecclesiastical establishments, instead of maintaining the purity and efficacy of Religion, have had a contrary operation. During almost fifteen centuries, has the legal establishment of Christianity been on trial. What have been its fruits? More or less in all places, pride and indolence in the Clergy; ignorance and servility in the laity; in both, superstition, bigotry and persecution. ${ }^{91}$

\section{Madison v. Scalia}

Although this is not the place to defend the Court's interpretations of the Establishment Clause, ${ }^{92}$ a cursory reading makes clear that the two concerns of political alienation and corruption of religion have animated much of the caselaw. The Court has understood its task to be to devise practical rules that would prevent these two evils. You may, of course, disagree with the Court. But the way to do that is to show that alienation and corruption are not, in fact, the consequences of the state activities that the Court has been inclined to invalidate under the Establishment Clause. ${ }^{93}$

These considerations are particularly pertinent to Justice Scalia's interpretation of the Establishment Clause. The idea that religion might be degraded by state sponsorship is entirely lost on Scalia. The closest he comes to acknowledging the Madisonian concerns about alienation and corruption is one passage in which he deems it relevant that the major monotheistic religions-Christianity, Islam, and Judaism-“combined account for $97.7 \%$ of all believers." exclusion here, nonbelievers are doubly excluded, since they are not even entitled to be part of the denominator. If one adds the nonbelievers, as enumerated in the 2004 Statistical Abstract of the United States which Scalia cites, the excluded adult population is 33 million out of 207 million, or 16 percent. $^{95}$

90 Id.

91 Id. at 9-10.

92 This would be hard to do because the doctrine is such a tangle. Steven Gey notes that one or more Justices had embraced ten different Establishment Clause standards, and some endorsed more than one, including standards that contradicted each other. Steven G. Gey, Life After the Establishment Clause, 110 W. VA. L. REV. 1, 35-37 (2007).

93 Many critics of the Court take precisely this approach. See, e.g., Laycock, supra note 67; Michael McConnell, The Selective Funding Problem: Abortions and Religious Schools, 104 HARV. L. REV. 989 (1991); Eugene Volokh, Equal Treatment Is Not Establishment, 13 NOTRE DAME J.L. ETHICS \& PUB. POL. 341 (1999).

94 McCreary County v. ACLU, 545 U.S. 844, 894 (2005) (Scalia, J., dissenting).

95 U.S. Census Bureau, Statistical ABstract OF THE United STATES: 2004-2005, at 55 (124th ed. 2004) (cited in McCreary County, 545 U.S. at 894). Further data on the number of people Scalia is leaving out are compiled in Frederick Mark Gedicks and Roger Hendrix, Uncivil Religion: Judeo- 
The numbers are in fact a bit more complicated than the Statistical Abstract suggests. The proportion of Americans who report having no religious preference doubled in the 1990s, from 7 percent in 1991 (which had been its level for almost 20 years) to 14 percent in 1998. However, most of the members of this category are in fact religious. More than half believe in God, more than half believe in life after death, about a third believe in heaven and hell, and 93 percent sometimes pray. The most careful study of this group concludes that the newer members are mostly "unchurched believers" who declare no religious preference in an effort to express their distance from the religious right. ${ }^{96}$

It is clear that these people are not interested in being part of the theistic triumphalism that Scalia wants to license. Similarly, Steven Gey observes that, in order to calculate the number of people excluded from Scalia's formula, one ought also to include the large number of theists who reject state sponsorship of religion, including " $[\mathrm{t}]$ raditional Roger Williamsstyle Baptists, Seventh-day Adventists, Jehovah's Witnesses, most Jews, many Presbyterians, and other modern nonfundamentalist Protestants." 97 Scalia does not explain his indifference to these people while he conspicuously includes Jews (whether they want inclusion or not) and Moslems, who together comprise fewer than 4 million Americans. ${ }^{98}$

\section{DUPES AND FELLOW TRAVELERS}

In short, the "originalism" that one now finds on the Supreme Court is a phony originalism which is opportunistically used to advance substantive positions that the judges find congenial. There are originalists who deserve to be taken seriously, but none of them are Supreme Court Justices. ${ }^{99}$

The conclusions of this Article do not in any way impugn the work of originalist scholars who are conscientiously striving to determine the original meaning of the Constitution. It is the scholars, not the judges, whose

Christianity and the Ten Commandments, 110 W. VA. L. REv. 275, 284-85 (2007); Gey, supra note 92, at 18-20, 45-47. The data on which the Census Bureau relies is described in detail in BARRY A. KOSMIN \& ARIELA KEYSAR, RELIGION IN A FREE MARKET (2006).

${ }^{96}$ Michael Hout \& Claude S. Fischer, Why More Americans Have No Religious Preference: Politics and Generations, 67 AM. SocIOLOGICAL REV. 165 (2002).

${ }^{97}$ Gey, supra note 92, at 20.

98 As Gey notes, most Jews are separationists. They thus are unlikely to want to be included in Scalia's numerator. Id. at 18 .

99 The wedge I have drawn here between professors and judges is generally correct, but it must unhappily be said that some "originalists," whom I will not name here, rushed to defend the Supreme Court's astonishing abuse of its power in Bush v. Gore, 531 U.S. 98 (2000). One can easily imagine what they would have said had the Court engaged in such contortions on behalf of Democrats. The dishonesty or self-deception of the Bush v. Gore majority is perhaps understandable: by reaching the result they did, they got something tangible that they badly wanted, a Republican President. But what, exactly, do scholars gain by mortifying their intellects in this way? They are worse than political hacks. They are public relations flacks for political hacks. 
work comprises this Symposium. The Justices' disingenuousness however raises the question what originalist scholars are, objectively, doing.

One thing that originalist scholarship will certainly do is stir the pot of constitutional interpretation, turning up new and potentially revolutionary meanings for old provisions. Those new meanings may subsequently be refuted by subsequent scholarship, as has happened with Cord and with the jurisdictional reading of the (incorporated) Establishment Clause. But the function of all this scholarship in the Supreme Court is somewhat different than its authors intend: "originalist" Justices opportunistically use the scholarship to attack areas of the law that they don't like. Since the conclusions of historical scholarship shift over time and since the judges are not constrained by the fact that a conclusion reached by some scholar at some time has since been refuted, the consequence is to expand the field of judicial discretion by presenting judges with a broad menu of possible interpretations, each of which have sufficient originalist credentials to qualify for citation in the U.S. Reports.

In his classic work of anticommunist propaganda, Masters of Deceit, then-FBI Director J. Edgar Hoover listed the various types of supporters upon whom the Communist Party relied for its nefarious ends. "The fellow traveler, while not a member, actively supports (travels with) the Party's program for a period of time." 100 Fellow travelers are valuable to the party precisely because they are not affiliated with it. "They are more valuable outside: as financial contributors, vocal mouthpieces, or contacts between Party officials and non-communists. They constitute, in fact, fronts for, and defenders of, the Communist Party."101 The party also depends on the "dupe," the person who "unknowingly is under Communist thought control and does the work of the Party."102

Hoover did not want to be too hard on the dupes. Most of them, he wrote, were "loyal, but deceived, citizens." 103 Most originalist scholars do not mean simply to be shills for the agenda of the Republican Party. ${ }^{104}$ They should, however, understand the function they are performing. They are being used.

\footnotetext{
100 J. Edgar Hoover, Masters of Deceit: THe Story of COMMUnism in AMERICA AND How TO FIGHT IT 88 (1958).

101 Id. at 89.

${ }^{102}$ Id. at 93.

103 Id. at 94 .

104 Some are fellow travelers, and some, for all I know, may even be members of the Party.
} 
N ORTHW ESTER N UNIVERS ITY LA W RE VIEW 